DOI: http://dx.doi.org/10.31558/2307-2296.2019.1.15

УДК 341.215.2:336

Савченко М. В., д.е.н., професор, Донецький національний університет імені Василя Стуса

\title{
КРЕДИТИ МІЖНАРОДНИХ ФІНАНСОВИХ ОРГАНІЗАЦІЙ ЯК ДЖЕРЕЛО СТАБІЛІЗАЦІЇ ФІНАНСОВОЇ СИСТЕМИ УКРАЇНИ
}

В статті досліджено вплив кредитів міжнародних фінансових організацій на фінансову систему України. Проаналізовано динаміку обсягів фінансових ресурсів, залучених від міжнародних фінансових організацій та МВФ для реалізації інвестиційних проектів України. Розглянуто позитивні і негативні сторони кредитування країни МВФ.

В статті обгрунтовано, що зовнішні запозичення є одним із реальних інструментів пом'якшення фінансових проблем та пожвавлення фінансової кон'юнктури в країні. Визначені чинники, що можуть призвести до загострення фінансової кризи: неефективний механізм залучення та використання позик, дефіцит державного бюджету та платіжного балансу.

Здійснена спроба побудови моделі зв'язку між обсягами кредитування міжнародними фінансовими організаціями та станом (профіцит/дефіцит) Державного бюджету України, офіційним курсом гривні до долара США, офіційними резервними активами Національного банку України. Основним науковим результатом дослідження стало прогнозування всіх факторних ознак побудованої моделі обсягів кредитування міжнародними фінансовими організаціями та на їх основі визначено рівень кредитування на наступний рік.

Ключові слова: міжнародна фінансова організація, кредити, співробітництво, МВФ, МБРР, СБРР, СІБ.

Рис. 8, Табл.5, Літ. 2.

\section{Савченко М. В.}

\section{КРЕДИТЫ МЕЖДУНАРОДНЫХ ФИНАНСОВЫХ ОРГАНИЗАЦИЙ КАК} ИСТОЧНИК СТАБИЛИЗАЦИИ ФИНАНСОВОЙ СИСТЕМЫ УКРАИНЫ

В статье исследовано влияние кредитов международных финансовых организаций на финансовую систему Украины. Проанализирована динамика объемов финансовых ресурсов, привлеченных от международных финансовых организаций и МВФ для реализации инвестиционных проектов Украины. Рассмотрены положительные и отрицательные стороны кредитования страны МВФ.

В статье обосновано, что внешние заимствования являются одним из реальных инструментов смягчения финансовых проблем и оживления финансовой конъюнктуры в стране. Определены факторы, которые могут привести к обострению финансового кризиса: неэффективный механизм привлечения и использования займов, дефицит государственного бюджета и платежного баланса.

Построена модель связи между объемами кредитования международными финансовыми организациями и состоянием (профицит / дефицит) Государственного бюджета Украины, официальному курсу гривни к доллару США, официальным резервными активами Национального банка Украины. Основным научным результатом исследования стало прогнозирования всех факторных признаков построенной модели объемов кредитования международными финансовыми организациями и на их основе определен уровень кредитования на следующий год.

Ключевые слова: международная финансовая организация, кредиты, сотрудничество, МВФ, МБРР, ЕБРР, ЕИБ. 


\section{Savchenko M.}

\section{LOANS TO INTERNATIONAL FINANCIAL ORGANIZATIONS AS THE SOURCE OF STABILIZATION OF THE FINANCIAL SYSTEM OF UKRAINE}

The article investigates the impact of international financial institutions' loans on the financial system of Ukraine. The dynamics of financial resources attracted from international financial organizations and the IMF for the implementation of investment projects of Ukraine are analyzed. Positive and negative aspects of IMF lending are considered.

The article argues that external borrowing is one of the real tools to alleviate financial problems and revitalize the financial situation in the country. Factors that may exacerbate the financial crisis are identified: inefficient mechanism for attracting and using loans, deficits of the state budget and the balance of payments.

An attempt has been made to build a model of correlation between lending volumes by international financial institutions and the state (surplus / deficit) of the State Budget of Ukraine, the official hryvnia to US dollar), official reserve assets of the National Bank of Ukraine. The main scientific result of the study was the forecasting of all factor features of the model of lending volumes of international financial institutions and the level of lending for the next year was determined.

Keywords: international financial organization, loans, cooperation, IMF, IBRD, EBRD, EIB.

Постановка проблеми. В умовах глобалізаційних викликів поступової популярності набирають питання зовнішньої фінансової допомоги, направленої на покращення добробуту населення та економічний розвиток держав. Згідно 3 Цілями розвитку тисячоліття основними результатами співпраці країн 3 міжнародними фінансовими організаціями $є$ трансформація народного господарства, впровадження новітніх інноваційних технологій, зміни економічного, політичного та соціального характеру та як результат покращення життя населення та подолання бідності. У наукових колах висловлюються різні позиції щодо наслідків такої фінансової допомоги та насамперед негативних для країн та суспільства.

Складність на шляху фінансової стабілізації та економічного зростання України значно зумовлена дефіцитом фінансових ресурсів. Останнім часом вітчизняні підприємства та установи корпоративного сектору частіше звертаються за додатковими ресурсами до світових фінансових ринків. Маючи високий нереалізований економічний потенціал Україні доцільніше розширяти можливості залучення фінансування міжнародними фінансовими організаціями з урахуванням системної диверсифікації форм i джерел надходження запозичених коштів. Все це вимагає переосмислення ролі міжнародних фінансових організацій у фінансуванні проектів у державному секторі України, а також осучаснення механізмів відповідного співробітництва, що допоможе оптимізувати використання зовнішніх кредитних ресурсів для потреб розвитку країни.

Однією 3 важливих науково-практичних проблем, яка постала перед наукою i потребує невідкладного вирішення, $\epsilon$ нагальна необхідність розроблення науково обгрунтованої концепції i ефективної стратегії співпраці України 3 міжнародними фінансовими організаціями.

Головними перевагами таких запозичень 3 погляду практиків $є$ доступ до значних грошових ресурсів, відносно низька їх вартість і триваліші (порівняно 3 внутрішніми) терміни залучення. Зовнішні запозичення є одним із реальних інструментів пом'якшення фінансових проблем та пожвавлення фінансової кон'юнктури в країні, але неефективний механізм залучення та використання позик, дефіцит державного бюджету та платіжного 
балансу є чинниками, що можуть призвести до загострення фінансової кризи і краху фінансової системи країни в цілому.

Аналіз останніх досліджень та публікацій. Дослідження проблеми правового аналізу міжнародних фінансових організацій як суб'єктів фінансової системи України проаналізовано в роботах таких науковців, як: Ю. В. Гаруст, Т. В. Кобзєва, Т. В. Кожухова, А. С. Марина, Я. І. Чайковський та інші.

Разом з тим вивчення опублікованих за досліджуваною проблемою робіт дозволило зробити висновок про те, що існує низка теоретичних і практичних питань взаємодії України з міжнародними фінансовими організаціями, які ще не повною мірою вивчені, досліджені та узагальнені.

Мета статті полягає у обгрунтуванні моделювання обсягів зовнішнього кредитування для забезпечення економічного розвитку країни й уникненні при цьому макроекономічних труднощів і проблем платіжного балансу в майбутньому.

Виклад основного матеріалу дослідження. Сьогодні роль міжнародних фінансових організацій дуже важко недооцінити, бо вони є найважливішою формою реалізації міжнародних відносин та джерелом стабілізації фінансової системи держави.

Сьогодні Україна є членом багатьох міжнародних фінансових організацій. Для того, щоб визначити механізми співробітництва України 3 міжнародними фінансовими організаціями, знайти найвигідніші форми такого співробітництва, необхідно провести аналіз результатів співпраці, виявити недоліки та розробити шляхи їх усунення.

За роки незалежності в Україні вже склалися тенденції до співпраці 3 окремими міжнародними фінансовими організаціями, причому систематичне кредитування держава отримує від Міжнародного банку реконструкції та розвитку (далі - МБРР), Свропейського банку реконструкції та розвитку (далі - СБРР), Свропейського інвестиційного банку (далі - СІБ) (рис. 1).

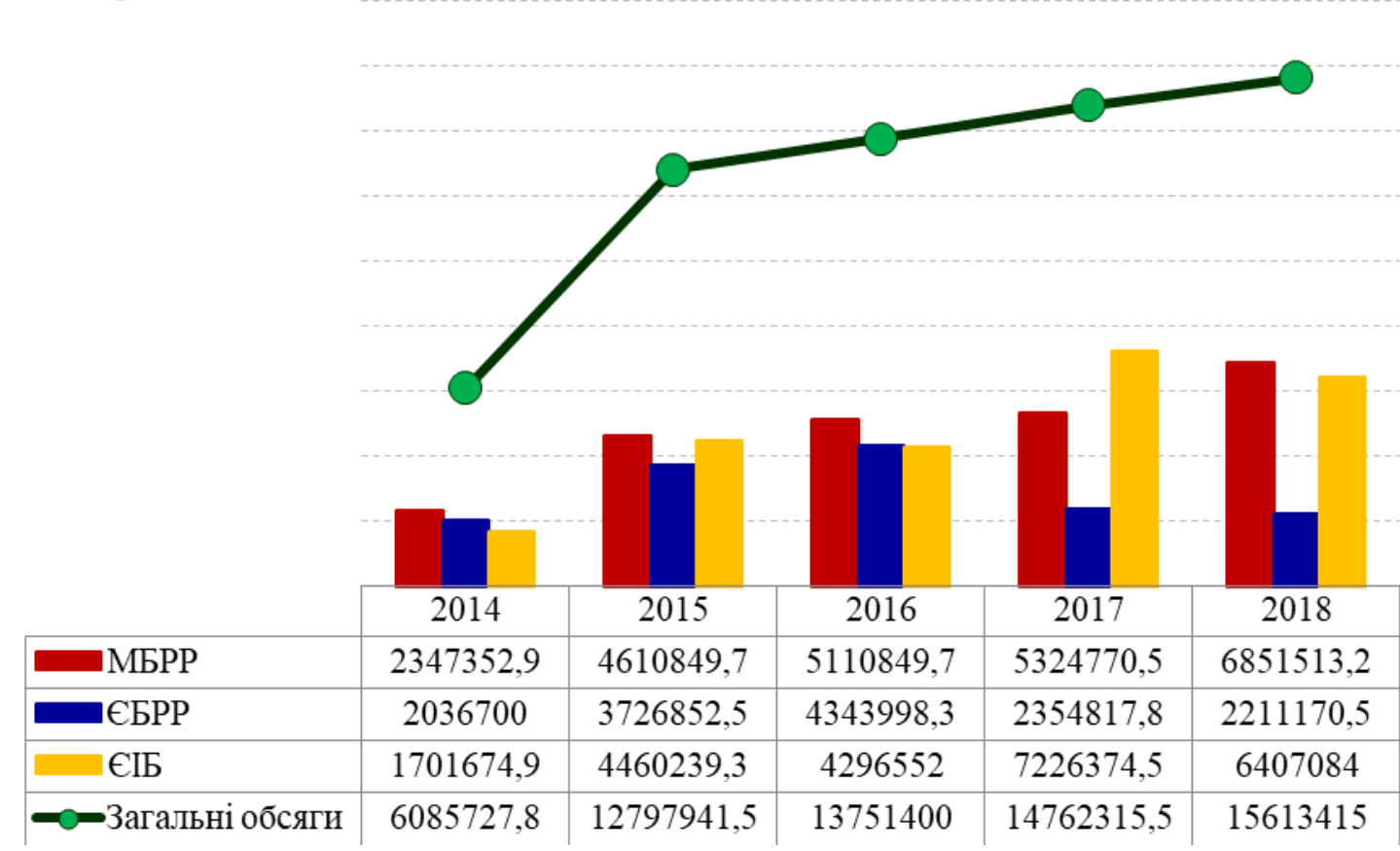

Рисунок 1 - Динаміка обсягів фінансових ресурсів, залучених від міжнародних фінансових організацій для реалізації інвестиційних проектів у 2014-2018 рр., тис. грн Джерело: складено автором 
За даними рис. 1 видно, що обсягів фінансових ресурсів, залучених від міжнародних фінансових організацій мають позитивну динаміку. Взагалі за роки співпраці Україна отримала від Європейського Союзу (далі - СС) 12 млдр євро та від Світового банку (далі - СБ) 11,9 млрд дол. США.

Країна отримує кошти і на безповоротній основі. Так, у 2018 р. офіційні трансферти від $\mathrm{CC}$, урядів, іноземних держав, міжнародних організацій, донорських установ наданосклали 2372 523,8 тис. грн.

Спираючись на вищеозначене можна стверджувати, що сьогодні, міжнародні фінансові відносини стали складовою фінансової системи країни з приводу акумулювання, розподілу та перерозподілу фінансових ресурсів та міжнародних фінансових потоків.

Закон України «Про вступ України до Міжнародного валютного фонду, Міжнародного банку реконструкції та розвитку, Міжнародної фінансової корпорації, Міжнародної асоціації розвитку та Багатостороннього агентства за гарантіями інвестицій» № 2402-XII від 03.06.1992 р. поклав початок співпраці України 3 міжнародними фінансовими організаціями, найбільш привабливим для України при цьому виступив Міжнародний валютний фонд [1].

Україна активно співпрацює з МВФ, використовуючи його фінансові і технічні ресурси 3 метою досягнення макроекономічної стабілізації та створення необхідних передумов для проведення економічних реформ.

Таке співробітництво здійснювалось переважно в рамках реалізації восьми програм - STF (системна трансформаційна позика), «Stand-by» (стабілізаційна позика, механізм розширеного фінансування (позика на підтримку розвитку), попереджувальний «Standby».

Загальний обсяг затвердженої суми та фактично виданих кредитів Міжнародним Валютним Фондом для України за весь період їх співпраці, розрахований на основі даних офіційних сайтів організацій, наведено на рис. 2.

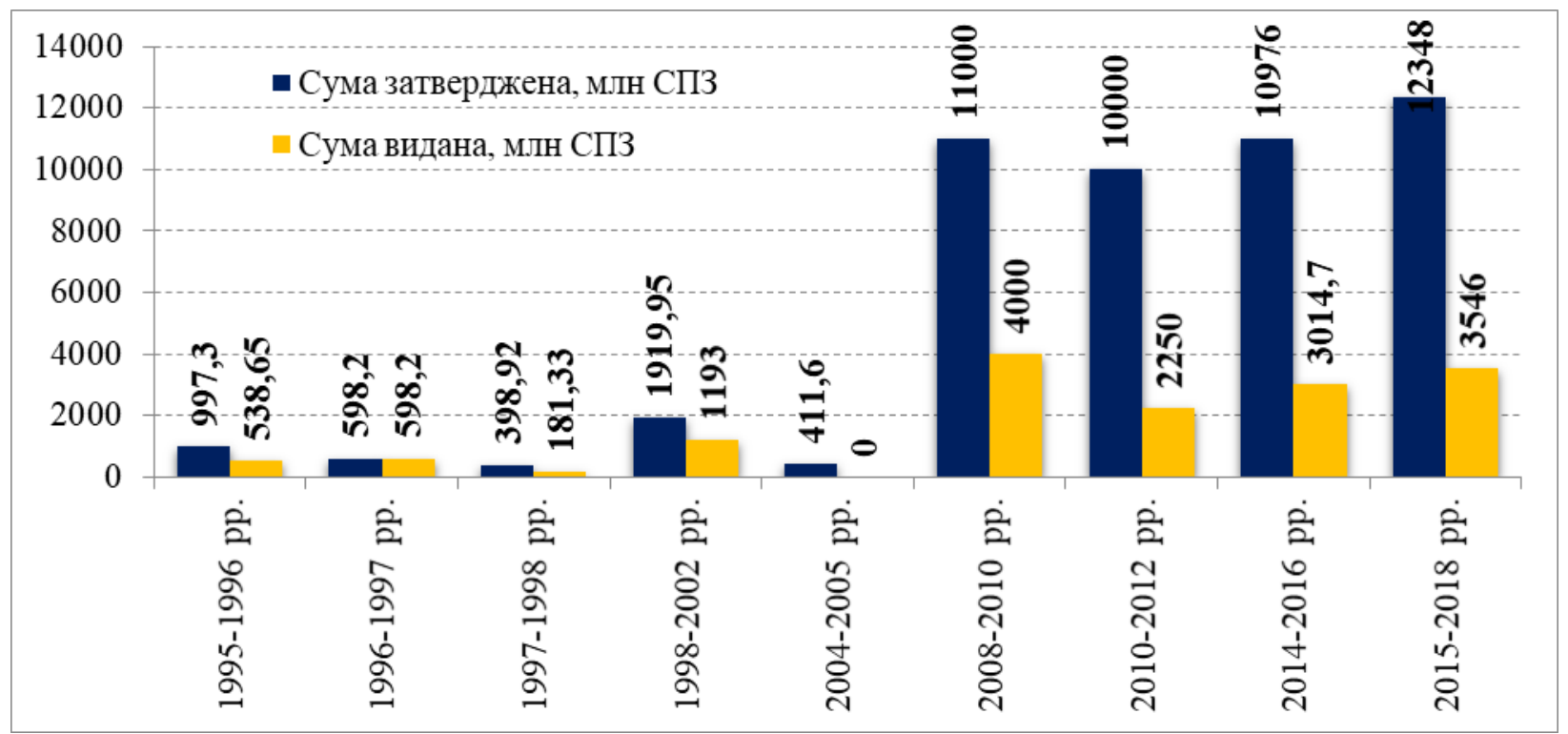

Рисунок 2 - Обсяги кредитування України МВФ в 1995-2018 рр., млн СПЗ Джерело: побудовано автором за даними [2]

Оскільки Україна перейшла від програми «Stand-by», яка застосовується для подолання короткострокових проблем платіжного балансу, до Механізму Розширеного Фінансування 
3 розряду комбінованої фінансової підтримки (пільговий), то це свідчить про те, що Україна зіткнулась 3 довгостроковими проблемами платіжного балансу, для яких $\mathrm{i}$ призначений EFF.

Як будь-яке явище в цьому світі, кредитування від МВФ має свої як позитивні так i негативні сторони. Серед позитивного впливу МВФ на Україну можна виділити на ступні пункти:

за кожен подальший транш Україна має виконати певні умови для його отримання, серед який і реформування. Отже, кредити МВФ стимулюють реформування в Україні. Яка якість проведення цих реформ це уже інше питання;

- за активного залучення коштів МВФ НБУ мав змогу сформувати золотовалютні резерви;

- щороку на основі даних, які Україна зобов'язалась надавати після підписання угоди про членство в МВФ, проводиться аналіз стану економіки України;

- під впливом МВФ набули чинності антикорупційні закони та розпочало свою діяльність Антикорупційне бюро. Що свідчить про перші позитивні зрушення в боротьбі з корупцією в країні;

- була модернізована фіскальна політика;

- $\quad$ під впливом МВФ НБУ почав активно контролювати діяльність комерційних банків, проводити регулярні обстеження.

Серед негативних чинників впливу можна виділити:

- $\quad$ стрімке зростання зовнішнього боргу України, який починаючи 32014 p. збільшився вчетверо. Створення негативного іміджу країні - показує іiі неплатоспроможність;

- проведення пенсійної реформи та зростання вартості комунальних платежів, спричинило масове соціальне невдоволення;

- як би там не було, але фактом залишається те, що реформи по суті проводяться за гроші, які надає МВФ, що свідчить про некомпетентність влади.

Головною проблемою співробітництва України та МВФ на сучасному етапі відносин $є$ нераціональне використання коштів, отриманих в кредит. Адже переважна кількість ресурсів спрямовується саме на «залатання дір» в бюджеті та підтримці торговельного балансу, а не сприяє розвитку, наприклад, секторів промисловості чи сільського господарства для реального росту економіки, збільшуючи зовнішню заборгованість країни.

У світовій практиці оцінка рівня зовнішньої заборгованості країни здійснюється 3 погляду економічного розвитку держави у зіставленні з основними макроекономічними показниками. У контексті цього здійснена спроба побудови модельізв'язку між обсягами кредитування міжнародними фінансовими організаціями (y) та станом (профіцит/дефіцит) Державного бюджету України $\left(x_{1}\right)$, офіційним курсом гривні до долара США $\left(x_{2}\right)$, офіційними резервними активами Національного банку України $\left(x_{3}\right)$ (табл. 1$)$.

Використовуючи метод найменших квадратів для множинної регресії отримані такі значення невідомих параметрів рівняння:

$$
y=2442,4-0,31 x_{1}+8,99 x_{2}+0,27 x_{3}
$$


Таблиця 1 - Основні макроекономічні показники України за 2003-2018 pp.

\begin{tabular}{|c|c|c|c|c|}
\hline Роки & $\begin{array}{l}\text { Загальний обсяг } \\
\text { кредитування, } \\
\text { міжнародними } \\
\text { фінансовими } \\
\text { організаціями, } \\
\text { млн дол. США } \\
(y)\end{array}$ & $\begin{array}{l}\text { Сальдо } \\
\text { державного } \\
\text { бюджету, млн грн } \\
\left(x_{1}\right)\end{array}$ & $\begin{array}{l}\text { Офіційний } \\
\text { гривні дурс } \\
\text { США, грн за } 100 \text { дол. } \\
\text { США } \\
\left(x_{2}\right)\end{array}$ & $\begin{array}{l}\text { Офіційні } \\
\text { резервні } \\
\text { активи, млн } \\
\text { дол. США } \\
\left(x_{3}\right)\end{array}$ \\
\hline 2003 & 10690 & $-1043,1$ & 533,27 & 6943 \\
\hline 2004 & 12154 & $-10217,0$ & 531,92 & 9715 \\
\hline 2005 & 11672 & $-7945,7$ & 512,47 & 19391 \\
\hline 2006 & 12664 & $-3777,0$ & 505,00 & 22358 \\
\hline 2007 & 13848 & $-9843,0$ & 505,00 & 32479 \\
\hline 2008 & 18544 & $-12500,7$ & 770,00 & 31543 \\
\hline 2009 & 26519 & $-35517,2$ & 798,50 & 26505 \\
\hline 2010 & 34760 & $-64265,5$ & 793,56 & 34576 \\
\hline 2011 & 37475 & $-23558,0$ & 796,76 & 31795 \\
\hline 2012 & 38659 & $-53445,2$ & 799,10 & 24546 \\
\hline 2013 & 37536 & $-64707,6$ & 799,30 & 20416 \\
\hline 2014 & 38792 & $-78052,8$ & 1188,67 & 7533 \\
\hline 2015 & 43445 & $-45167,5$ & 2184,47 & 13300 \\
\hline 2016 & 45605 & $-70130,2$ & 2555,13 & 15539 \\
\hline 2017 & 48989 & $-47849,6$ & 2659,66 & 18808 \\
\hline 2018 & 50462 & $-59247,9$ & 2720,05 & 20820 \\
\hline
\end{tabular}

Джерело: побудовано автором за даними [2]

Перевірка моделі на адекватність дозволила обчислити певні їі характеристики (табл. 2).

Таблиця 2 - Характеристики моделі

\begin{tabular}{|l|l|l|l|}
\hline Характеристики моделі & Значення & Характеристики моделі & Значення \\
\hline $\begin{array}{l}\text { Коефіцієнт множинної кореляції } \\
\left(R_{x y}\right)\end{array}$ & 0,952 & $\begin{array}{l}\text { Парні коефіцієнти кореляції: } \\
\text { в т.ч. }\end{array}$ & \multicolumn{2}{|l|}{} \\
\hline Коефіцієнт детермінації $(d)$ & 0,905 & 1) Сальдо державного бюджету $\left(r_{x l y}\right)$ & $-0,857$ \\
\hline F-критерій розрахунковий $(F р о з р)$ & 38,299 & $\begin{array}{l}\text { 2) Офіційний курс гривні до долара } \\
\text { США }\left(r_{x 2 y}\right)\end{array}$ & 0,806 \\
\hline $\begin{array}{l}\text { Коефіцієнти еластичності, \%: } \\
\text { в т.ч. }\end{array}$ & 3) Офіційні резервні активи $\left(r_{x z y}\right)$ & $-0,014$ \\
\hline$E_{i l}=$ & 0,384 & & \\
\hline$E_{i 2}=$ & 0,348 & & \\
\hline$E_{i 3}=$ & 0,186 & & \\
\hline
\end{tabular}

Джерело: розраховано автором

За даними табл. 2 можна зробити висновки:

1) між чинниками, які досліджувались в моделі та обсягами міжнародного кредитування існує досить міцний зв'язок $(\mathrm{Rxy}=0,952)$;

2) коефіцієнт детермінації свідчить, що 90,5 \% зміни обсягу міжнародних запозичень залежить від факторів, які включені до моделі, а 9,5\% - це вплив інших 
чинників, що наразі не досліджувались. Серед них можна виділити сальдо платіжного балансу, обсяг ВВП, інфляційні очікування, стабілізація економічної ситуації в країні тощо;

3) попарні коефіцієнти кореляції вказують, що найбільший зв'язок $\left(r_{x l y}=-0,857\right)$ існує між обсягом кредитів міжнародних фінансових організацій та сальдом державного бюджету. Значення коефіцієнта парної кореляції показує: чим більшим є бюджетний дефіцит, тим у більшими стають розміри міжнародних кредитів міжнародних фінансових організацій (рис. 3, 4).

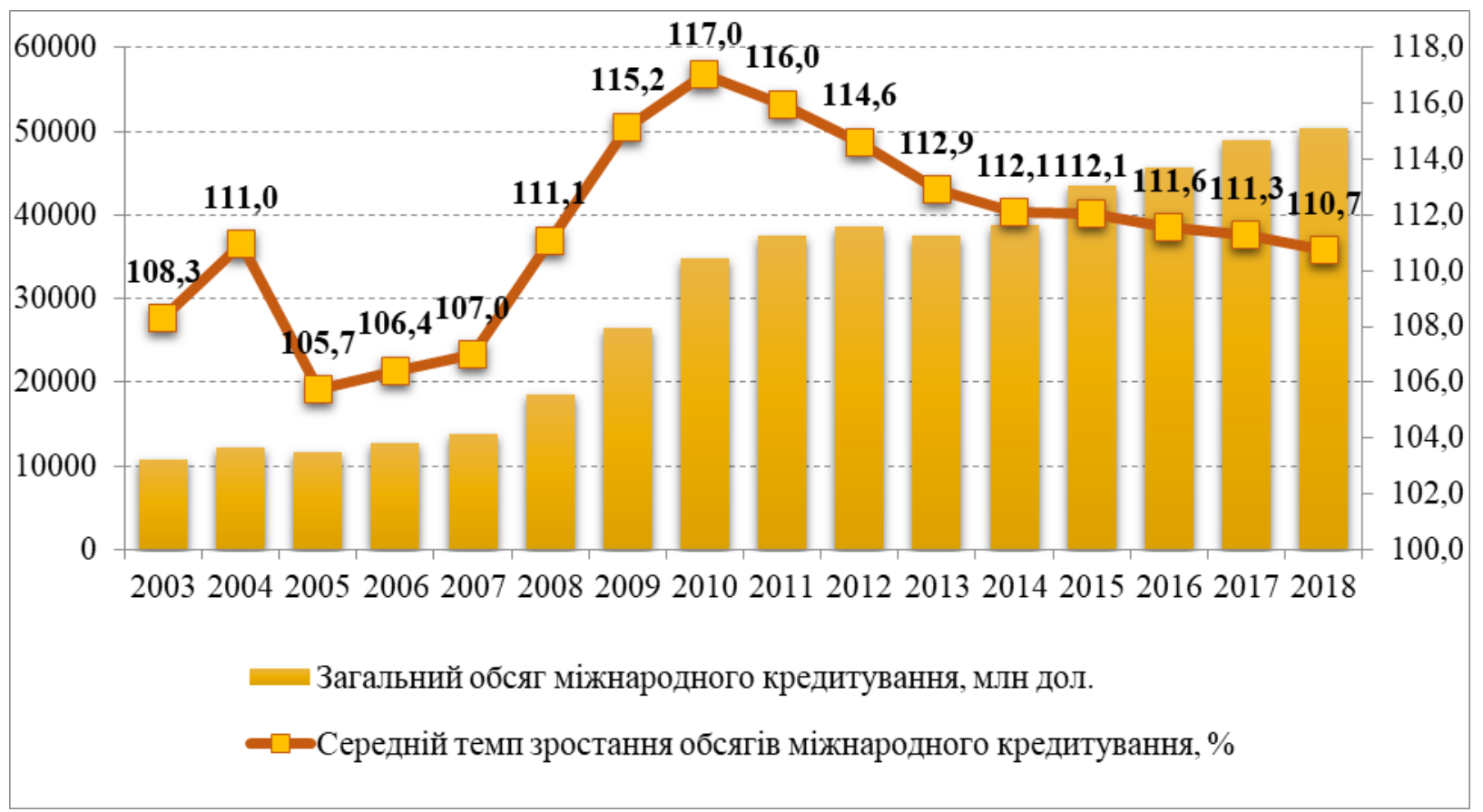

Рисунок 3 - Середній темп зростання обсягів кредитування України міжнародними фінансовими організаціями в 2003-2018 рр.

Джерело: побудовано автором за даними табл. 1

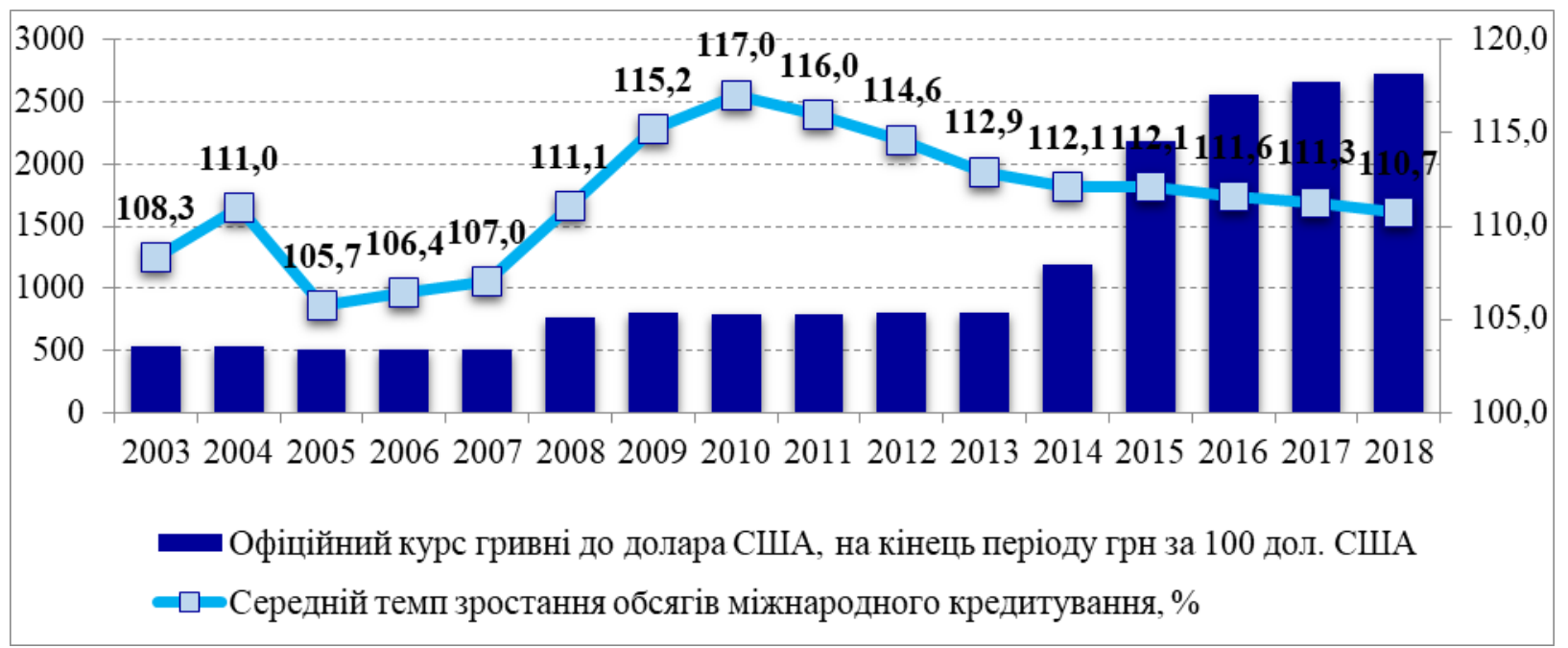

Рисунок 4 - Вплив зміни курсу гривні до долара США на темп зростання обсягів міжнародного кредитування України в 2003-2017 pp.

Джерело: побудовано автором за даними табл. 1 
Тому на виконання зазначених функцій та збільшення розмірів золотовалютних резервів органам грошово-кредитного регулювання доводиться шукати можливості залучення іноземної валюти через позики на зовнішніх світових ринках $\left(r_{x 3 y}=-0,014\right)$. При цьому, значну роль також відіграє і курс гривні відносно долара США $\left(r_{x 2 y}=0,806\right)$.

Поряд 3 цим, зв'язок між обсягом міжнародних запозичень та дефіцитом (-), профіцитом $(+)$ Державного бюджету України $\left(r_{x 1 y}=-0,857\right)$ є оберненим і свідчить про збільшення кредитів для покриття витрат в умовах зростання дефіциту Державного бюджету.

Перевірка розрахованих коефіцієнтів на значущість за критерієм Фішера підтвердили адекватність моделі (1) статистичним даним (рис. 5).

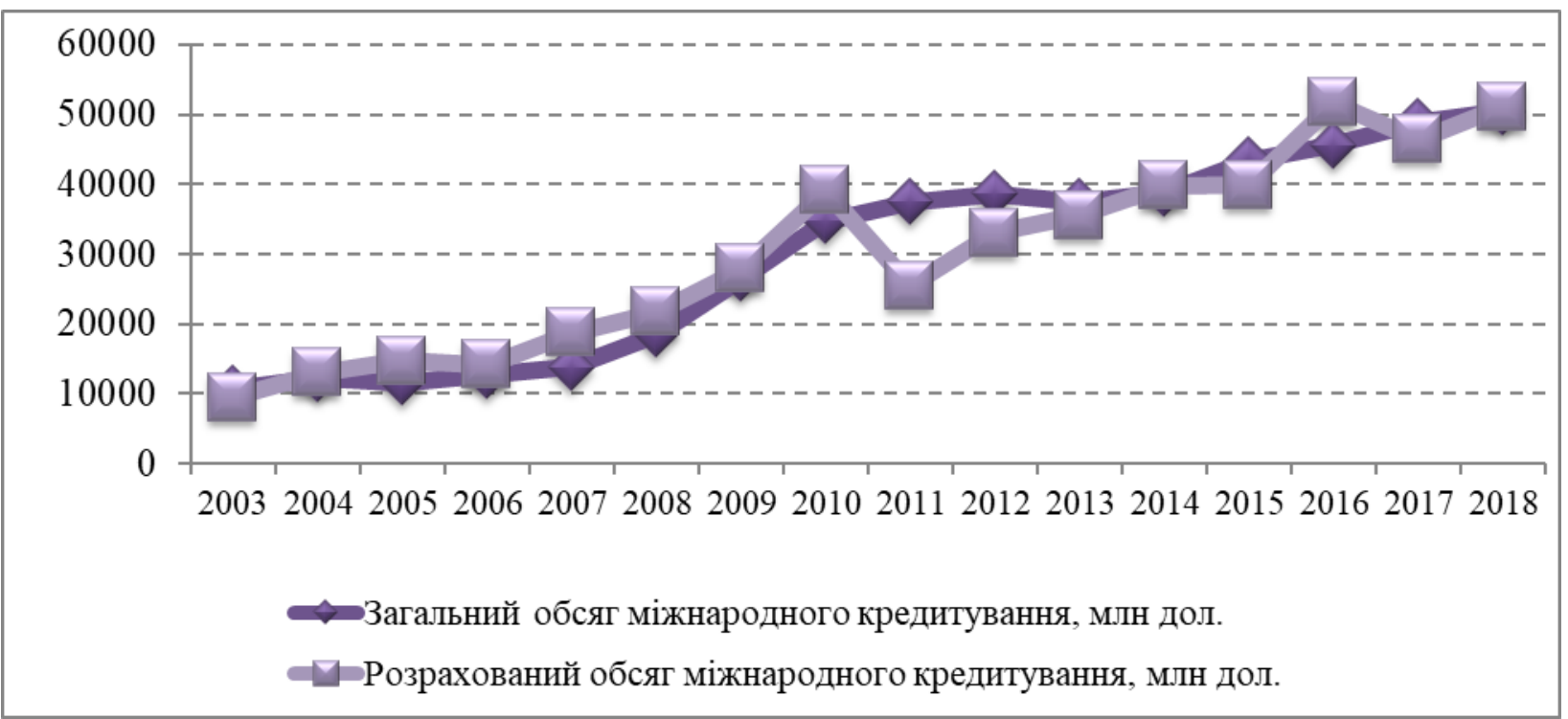

Рисунок 5 - Графік фактичних і розрахункових значень обсягу кредитування України міжнародними фінансовими організаціями в 2003-2018 pр.

Джерело: побудовано автором за даними [2]

Це також ілюструє рис. 5, на якому спостерігається незначне відхилення фактичного й розрахункового значення обсягу кредитування міжнародними фінансовими організаціями, а обчислені коефіцієнти еластичності дозволяють здійснити економічну інтерпретацію моделі, яка наведена в табл. 3.

Таблиця 3 - Економічна інтерпретація моделі загального обсягу кредитування міжнародними фінансовими організаціями України

\begin{tabular}{|l|l|l|l|l|}
\hline Фактор & $\begin{array}{l}\text { Напрямок } \\
\text { зміни }\end{array}$ & $\begin{array}{l}\text { Кількісні } \\
\text { значення } \\
\text { зміни }\end{array}$ & Наслідки & $\begin{array}{l}\text { Кількісні } \\
\text { значення } \\
\text { наслідків }\end{array}$ \\
\hline $\begin{array}{l}\text { 1. Дефіцит (-), } \\
\text { профіцит } \\
\text { Державного бюджету }\end{array}$ & $\begin{array}{l}\text { Збільшення } \\
\text { дефіциту }\end{array}$ & $1 \%$ & $\begin{array}{l}\text { Збільшення обсягу } \\
\text { зовнішніх запозичень }\end{array}$ & 0,384 \\
\hline $\begin{array}{l}\text { 2. Офіційний курс } \\
\text { гриві до долара } \\
\text { США }\end{array}$ & $\begin{array}{l}\text { Знецінення } \\
\text { гривні }\end{array}$ & $1 \%$ & $\begin{array}{l}\text { Збільшення обсягу } \\
\text { міжнародних кредитів }\end{array}$ & 0,348 \\
\hline $\begin{array}{l}\text { 3. Офіційні резервні } \\
\text { активи }\end{array}$ & $\begin{array}{l}\text { Зростання } \\
\text { резервів }\end{array}$ & $1 \%$ & $\begin{array}{l}\text { Збільшення обсягу позик } \\
\text { на світових ринках }\end{array}$ & 0,186 \\
\hline
\end{tabular}

Джерело: побудовано автором 
Для обчислення за моделлю (1) обсягу кредитування міжнародними фінансовими організаціями у 2019 р. спрогнозовано дефіцит (-), профіцит (+) Державного бюджету України, офіційний курс гривні до долара США та офіційні резервні активи (рис. 6-8, табл. 4).

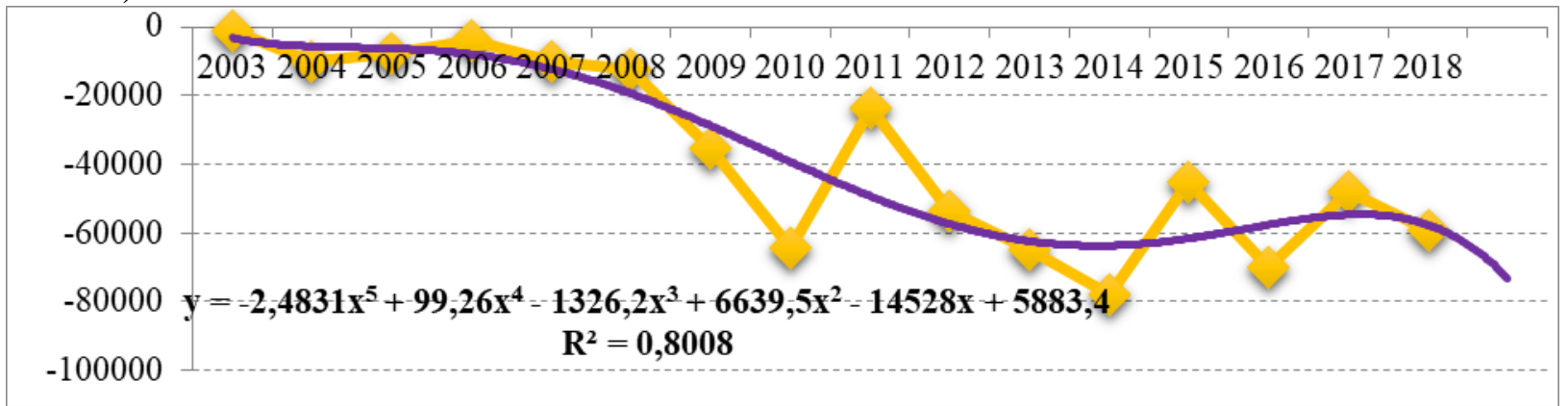

Рисунок 6 - Динаміка дефіциту (-), профіциту (+) Державного бюджету України в 20032018 рр., млн грн

Джерело: побудовано автором за даними табл. 1

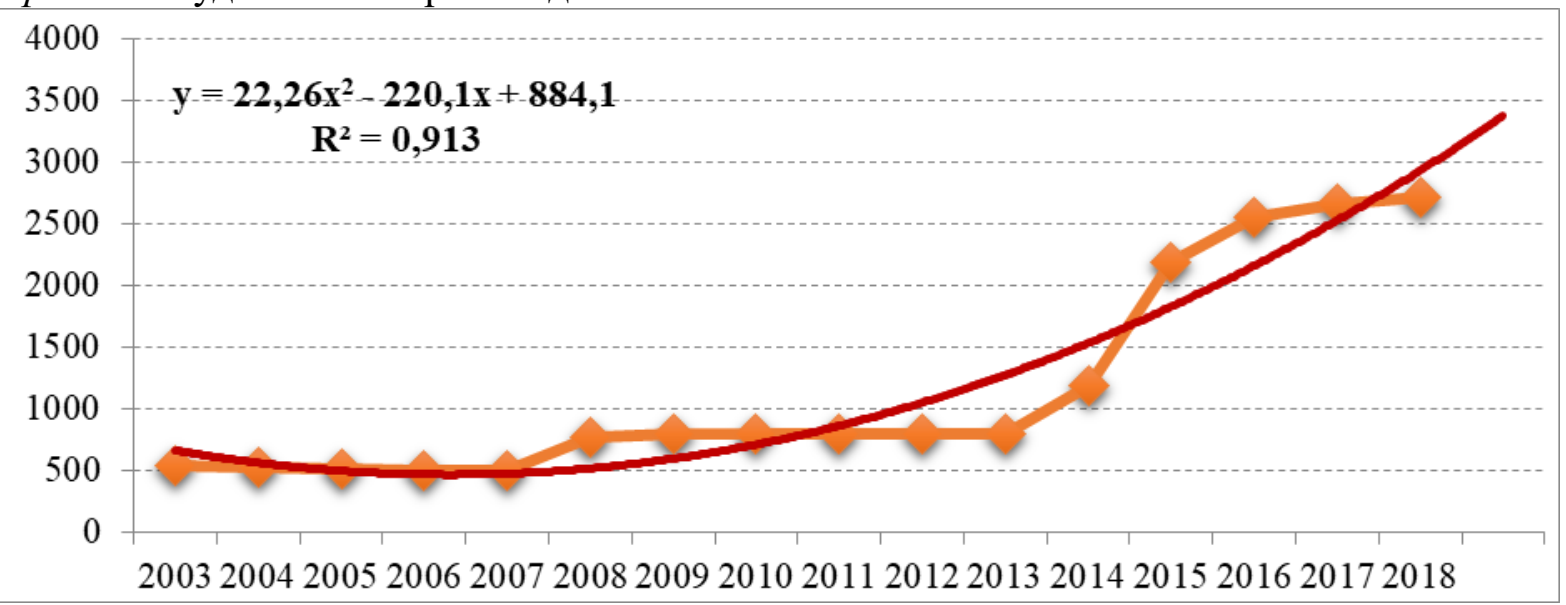

Рисунок 7 - Динаміка офіційного курсу гривні до долара США в 2003-2018 pр.

Джерело: побудовано автором за даними табл. 1

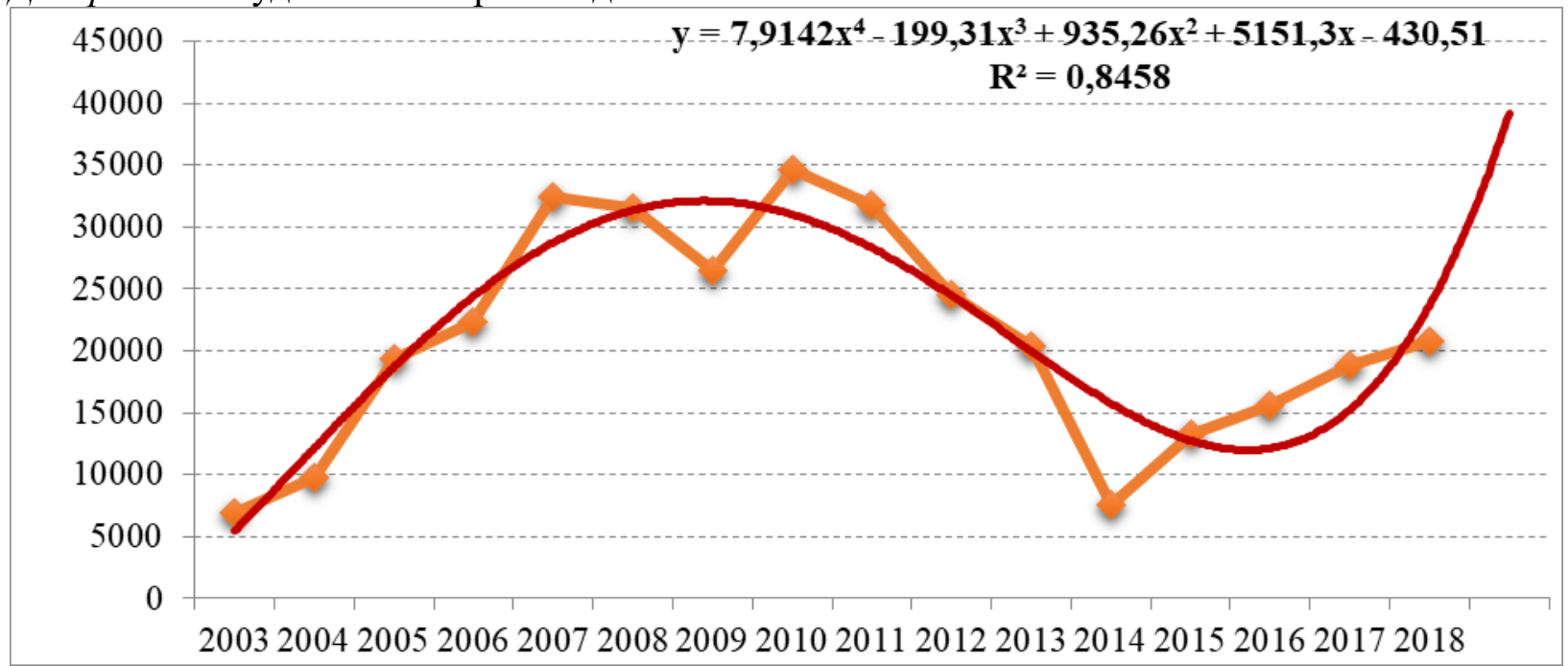

Рисунок 8 - Динаміка офіційних резервів в 2003-2018 рр., млн дол.

Джерело: побудовано автором за даними табл. 1 
Таблиця 4 - Прогнозні значення факторів моделі загального обсягу кредитування України міжнародними фінансовими організаціями

\begin{tabular}{|l|l|l|}
\hline Показники & Модель & $\begin{array}{l}\text { Прогноз на } \\
2019 \text { p. }\end{array}$ \\
\hline $\begin{array}{l}\text { Дефіцит (-), профіцит (+) } \\
\text { Державного бюджету, млн грн }\end{array}$ & $\begin{array}{l}\mathrm{y}=-2,4831 \mathrm{x}^{5}+99,26 \mathrm{x}^{4}-1326,2 \mathrm{x}^{3}+ \\
6639,5 \mathrm{x}^{2}-14528 \mathrm{x}+5883,4\end{array}$ & $-73250,2$ \\
\hline $\begin{array}{l}\text { Офіційний курс до долара США, } \\
\begin{array}{l}\text { на кінець періоду грн. за 100 дол. } \\
\text { США }\end{array}\end{array}$ & $\mathrm{y}=22,26 \mathrm{x}^{2}-220,1 \mathrm{x}+884,1$ & 3575,5 \\
\hline $\begin{array}{l}\text { Офіційні резервні активи, млн } \\
\text { дол. США }\end{array}$ & $\begin{array}{l}\mathrm{y}=7,9142 \mathrm{x}^{4}-199,31 \mathrm{x}^{3}+935,26 \mathrm{x}^{2}+ \\
5151,3 \mathrm{x}-430,5\end{array}$ & 39223,6 \\
\hline
\end{tabular}

Джерело: розраховано автором

Підставивши отримані результати у модель (1) маємо у короткостроковому періоді прогнозний обсяг кредитування України міжнародними фінансовими організаціями (табл. 5).

Таблиця 5 - Прогноз обсягу кредитування України міжнародними фінансовими організаціями

\begin{tabular}{|l|l|l|l|l|}
\hline & 2018 & 2019 & \multicolumn{2}{|l|}{ Відхилення } \\
\cline { 4 - 5 } & & млн дол. & $\%$ \\
\hline $\begin{array}{l}\text { Загальний обсяг кредитування, } \\
\text { млн дол. США }\end{array}$ & 50462,0 & 67884,0 & 17422,0 & 34,5 \\
\hline
\end{tabular}

Джерело: розраховано автором

Підставивши отримані результати у модель (1) розраховано у короткостроковому періоді прогнозний обсяг міжнародного кредитування України. Отже, протягом 2019 р. зовнішні запозичення можуть зрости більше, ніж на 34,5 \% і скласти 67884,0 млн дол.

Висновки. Таким чином, для забезпечення сталого економічного зростання i зниження фінансових ризиків Україна потребує вирішення низки важливих питань і має протистояти як зовнішнім, так і внутрішнім викликам. Як свідчить практика, продовження співробітництва України 3 міжнародними фінансовими організаціями $є$ доцільним i виправданим. Проте для підвищення ефективності кредитів міжнародних фінансових організацій в Україні необхідно подальше вдосконалення організації залучення, використання й погашення позик, обмеження й поступова відмова від іноземних кредитів на покриття дефіциту бюджету, коли дефіцит утворюється не за рахунок розширення інвестицій; забезпечення незв'язаного характеру кредитів, щоб позики стимулювали національне виробництво, а не використовувалися для імпорту товарів тощо. Відповідно, співробітництво з міжнародними фінансовими організаціями та установами, спрямоване на залучення фінансових коштів, сприяє підвищенню стабільності фінансової системи України.

1. Закон України «Про вступ України до Міжнародного валютного фонду, Міжнародного банку реконструкції та розвитку, Міжнародної фінансової корпорації, Міжнародної асоціації розвитку та Багатостороннього агентства за гарантіями інвестицій» № 2402-XII від 03.06.1992 p. Верховна Рада України URL: http://zakon5.rada.gov.ua/laws/show/2402-12/ 2. Державна служба статистики України. Офіційний сайт. URL: http://kved.ukrstat.gov.ua/ 